\title{
Effect of Low-Energy Electron Irradiation on DNA Damage by $\mathrm{Cu}^{2+}$ Ion
}

\author{
Hyung-Ah Noh', Yeunsoo Park², Hyuck Cho ${ }^{1, *}$ \\ ${ }^{1}$ Physics Department, Chungnam National University, Daejeon, Korea; ${ }^{2}$ Plasma Technology Research Center, National Fusion Research Institute, Gunsan, \\ Korea
}

\section{Original Research}

Received October 17, 2016

Revision November 8, 2016

Accepted January 11,2017

Corresponding author: Hyuck Cho

Physics Department, Chungnam National University, 99 Daehak-ro, Yuseong-gu,

Daejeon 34134, Korea

Tel: +82-42-821-6542,

Fax: +82-42-823-0919,

E-mail: hcho@cnu.ac.kr

This is an Open-Access article distributed under the terms of the Creative Commons Attribution NonCommercial License (http://creativecommons.org/ licenses/by-nc/4.0) which permits unrestricted noncommercial use, distribution, and reproduction in any medium, provided the original work is properly cited.

Copyright $\odot$ 2017The Korean Association for Radiation Protection

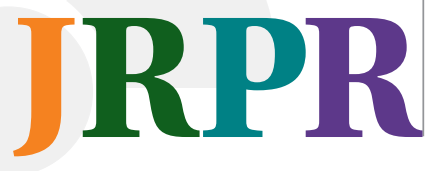

Background: The combined effect of the low energy electron (LEE) irradiation and $\mathrm{Cu}^{2+}$ ion on DNA damage was investigated.

Materials and Methods: Lyophilized pBR322 plasmid DNA films with various concentrations (1-15 $\mathrm{mM})$ of $\mathrm{Cu}^{2+}$ ion were independently irradiated by monochromatic LEEs with $5 \mathrm{eV}$. The types of DNA damage, single strand break (SSB) and double strand break (DSB), were separated and quantified by gel electrophoresis.

Results and Discussion: Without electron irradiation, DNA damage was slightly increased with increasing $\mathrm{Cu}$ ion concentration via Fenton reaction. LEE-induced DNA damage, with no $\mathrm{Cu}$ ion, was only $6.6 \%$ via dissociative electron attachment (DEA) process. However, DNA damage was significantly increased through the combined effect of LEE-irradiation and $\mathrm{Cu}$ ion, except around $9 \mathrm{mM} \mathrm{Cu}$ ion. The possible pathways of DNA damage for each of these different cases were suggested.

Conclusion: The combined effect of LEE-irradiation and $\mathrm{Cu}$ ion is likely to cause increasing dissociation after elevated transient negative ion state, resulting in the enhanced DNA damage. For the decrease of DNA damage at around 9-mM Cu ion, it is assumed to be related to the structural stabilization due to DNA inter- and intra-crosslinks via $\mathrm{Cu}$ ion.

Keywords: DNA damage, Copper ion, Electron beam, Dissociative electron attachment

\section{Introduction}

Since Sanche and the collaborators have pioneered the investigation of DNA damage induced by low-energy electrons (LEEs) irradiation [1], it has been established that LEEs can cause DNA damages such as single-strand break (SSB), double-strand break (DSB), base lesion, and cross-links between nucleobases. LEEs of having energies not enough to ionize DNA molecules can react with DNAs and their subunits and lead to various DNA damages indirectly. For example, Boudaiffa et al. [1] have shown that LEEs with less than $15 \mathrm{eV}$ can induce DNA damages on DNA films and explained the observation with dissociative electron attachment (DEA) process [2-8]. However, DNA in vivo is surrounded by many other molecules such as proteins and metal ions as well as $\mathrm{H}_{2} \mathrm{O}$ and interacts with these molecules. Among these interactants, metal ions are important catalysts for oxidative damaging reactions in DNA and other biomolecules [9-13]. For example, it is well established that oxidative DNA damage in the presence of Fe ions in the solution has occurred via Fenton reactions [14, 15]. Motivated by these important 
and independent roles of LEEs and metal ions, we have previously reported the combined effect of LEE-irradiation and $\mathrm{Fe}^{3+}$ ion on DNA damage [16]. Briefly summarizing the experiment, lyophilized pBR322 plasmid DNA films with various concentrations (0-7 mM) of $\mathrm{Fe}^{3+}$ ion were independently irradiated by monochromatic LEEs with 3 or $5 \mathrm{eV}$ energies. After the irradiation, DNA- $\mathrm{Fe}^{3+}$ films were recovered and analyzed by the agarose gel electrophoresis. In the case of non-irradiated DNA- $\mathrm{Fe}^{3+}$ films, there was a little DNA damage $(<10 \%)$ for $\mathrm{Fe}^{3+}$ ion up to $7 \mathrm{mM}$ concentration. In the case of irradiated DNA films without $\mathrm{Fe}^{3+}$ ion, again there was only a little DNA damage $(<3 \%)$. However, in the case of electron-irradiated DNA- $\mathrm{Fe}^{3+}$ films, DNA damage was enhanced considerably. A single effect of either $\mathrm{Fe}^{3+}$ ion or LEE-irradiation did not cause a significant DNA damage, but when these two components were combined DNA damage was significantly increased compared to the sum of the damages caused both by $\mathrm{Fe}^{3+}$ ion and by LEE-irradiation independently. Stimulated by this result, we have done the similar investigation with copper ion $\mathrm{Cu}^{2+}$, another transition metal ion, to see how they behave similarly or differently from $\mathrm{Fe}^{3+}$.

Both $\mathrm{Fe}$ and $\mathrm{Cu}$ ions are transition metal ion and they share some common characters while show some differences. Transition metal ions such as cobalt(II), copper(II) have different binding characteristics toward DNA. They bind almost exclusively by coordinating to the N7 position of purine, especially of guanine [17]. Copper has long been biocidal tools from the ancient era and is one of a relatively small group of metallic elements that are essential to human health [18]. Catalytic copper, because of its mobilization and redox activity, is believed to play a central role in the formation of reactive oxygen species that bind very fast to DNA, and produce damage by breaking the DNA strands or modifying the bases and/or deoxyribose leading to carcinogenesis [19].

Following the similar methods as done in the $\mathrm{Fe}^{3+}$ case, in this report we investigated the effects of LEE-irradiation and $\mathrm{Cu}^{2+}$ ion on DNA damage. The multilayered DNA- $\mathrm{Cu}^{2+}$ films were prepared by lyophilization technique and irradiated by $5 \mathrm{eV}$ electrons. After LEE-irradiations, the irradiated DNA$\mathrm{Cu}^{2+}$ films were analyzed by electrophoresis.

\section{Materials and Methods}

Plasmid DNA pBR322 was purchased from New England BioLabs Inc. This DNA molecule is a commonly used, double-stranded and supercoiled DNA with 4,361 bp in length and $2.83 \times 10^{6}$ daltons in weight. Cupric chloride $\left(\mathrm{CuCl}_{2}\right)$ was purchased from Sigma-Aldrich Chemical Co. (St. Louis, MO). All other reagents and solvents were purchased from Sigma-Aldrich Chemical Co. and used as received without further purification. SYBR GREEN I $(10,000 \times)$ as a DNA dye was purchased from Invitrogen and the concentration of SYBR GREEN I was diluted to $100 \times$ with dimethyl sulfoxide (DMSO) stock solution. Tantalum (Ta) plate was purchased from Goodfellow Cambridge Limited (Huntingdon, UK) and was cut into $12 \mathrm{~mm} \times 12 \mathrm{~mm}$ square pieces for use as DNA film substrate.

To prepare dried DNA films on Ta plates, a home-made lyophilizer was used [16]. In treating plasmid DNA and $\mathrm{CuCl}_{2}$, nanopure water (distilled and deionized water $(18.2 \mathrm{M} \Omega \cdot \mathrm{cm}$, $25^{\circ} \mathrm{C}$; $\mathrm{ddH}_{2} \mathrm{O}$ )) was used. pBR322 DNA solution was prepared mixed with TE (Tris-HCl 10 mM, EDTA 1 mM, pH 8.0) buffer to dilute to a concentration of $0.05 \mu \mathrm{g} \mu \mathrm{L}^{-1}$, and $\mathrm{CuCl}_{2}$ solutions mixed with $\mathrm{H}_{2} \mathrm{O}$ to make eight different concentrations from $0 \mathrm{mM}$ to $15 \mathrm{mM}$. The prepared pBR322 DNA solution and $\mathrm{CuCl}_{2}$ solutions were individually mixed in a $0.5 \mathrm{~mL}$ microcentrifuge tube to make DNA-Cu${ }^{2+}$ complex. Each DNA-Cu $\mathrm{Cu}^{2+}$ mixture solution (with a volume of $9 \mu \mathrm{L}$ ) was carefully dropped on a chemically clean Ta plate. The dropped DNA-Cu ${ }^{2+}$ solutions were spread on the Ta plates to a circular shape with a $5 \mathrm{~mm}$ diameter. Immediately after, the solutions became frozen using liquid nitrogen and then transferred to the small vacuum chamber of the lyophilizing system. Water molecules in the DNA-Cu${ }^{2+}$ solutions were extracted by the cryogenic sorption pump, and finally dried DNA- $\mathrm{Cu}^{2+}$ films with about 5 monolayers (ML) on the Ta plates were obtained. For each run of the experiments, eight DNA- $\mathrm{Cu}^{2+}$ films were prepared and loaded into another vacuum chamber for LEE-irradiation. To make the DNA films without $\mathrm{Cu}$ ion, the similar procedure was followed.

The figures and the details of an experimental setup for LEE-irradiation on DNA films were given in the previous report [16]. In brief, it consists of an electron gun (E-gun), a Faraday cup, and a sample holder. The E-gun can generate a monoenergetic electron beam having $0.5 \mathrm{eV}$ resolution over the entire sample surface. Each DNA film was individually irradiated with constant irradiation time, beam current, and incident electron energy. For 5-minute irradiation time, it was estimated a total exposure of approximately $1.8 \times 10^{14}$ electrons per DNA film. The irradiation of DNA film was carried out under ultra-high vacuum of about $10^{-9}$ torr.

Gel electrophoresis was used to identify and quantify DNA 
damage induced by LEE-irradiation and $\mathrm{Cu}^{2+}$ ion. The DNA films were recovered from Ta plates with $9 \mu \mathrm{L}$ of TE buffer. After that, $1 \mu \mathrm{L}$ of SYBR GREEN $1(100 \times)$ and $2 \mu \mathrm{L}$ of loading buffer $(6 \times)$ were added to the recovered DNA solution. Thus, prepared DNA samples were loaded with DNA marker molecule onto $1 \%$ agarose gel submerged under TAE solution $(1 \times)$. After electrophoresis at $50 \mathrm{~V}$ for 35 minutes, separated DNA bands were photographed using gel-documentation system (ImageQuent300, GE Healthcare, Buckinghamshire, UK), and each type of DNA damage was quantified using ImageQuent program. All data shown in the figures and the table indicate an average values with corresponding standard deviations of four to eight independent experiments.

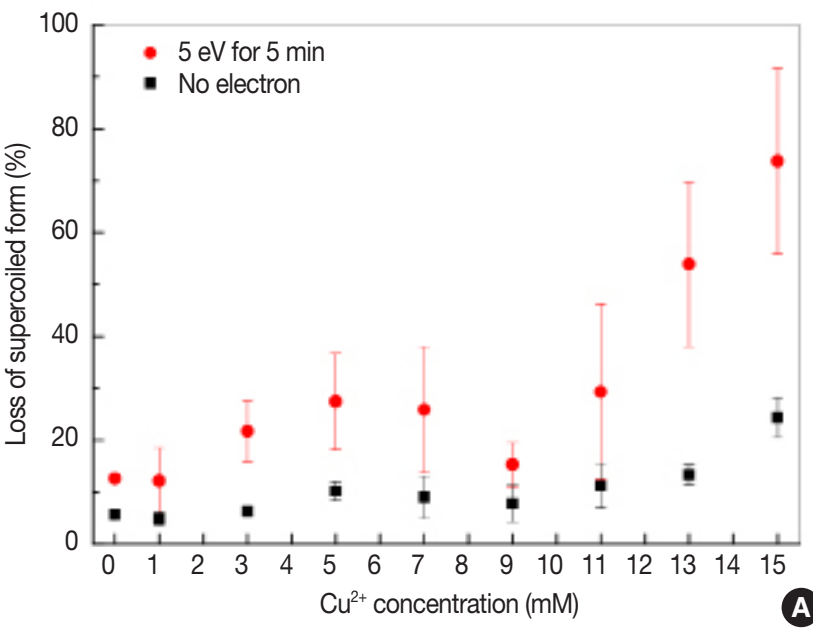

\section{Results and Discussion}

The structure of supercoiled DNA can be changed to circular or linear DNA as the results of strand breaks, which allows us to identify the types of DNA damage induced by LEEirradiation and $\mathrm{Cu}^{2+}$ ion using gel electrophoresis. The initial state of plasmid pBR322 DNA is mostly supercoiled-type with less than 5\% nicks. Figure 1A shows the results for the gel electrophoresis of DNA damages induced by LEE-irradiation with $5 \mathrm{eV}$ on the DNA-Cu${ }^{2+}$ films as a function of $\mathrm{Cu}^{2+}$ concentration (1-15 mM). The solid squares indicate the loss of supercoiled DNA induced by $\mathrm{Cu}^{2+}$ ion concentrations without $5 \mathrm{eV}$ electron irradiation and the solid circles indicate the loss of supercoiled DNA for the combined effect of 5

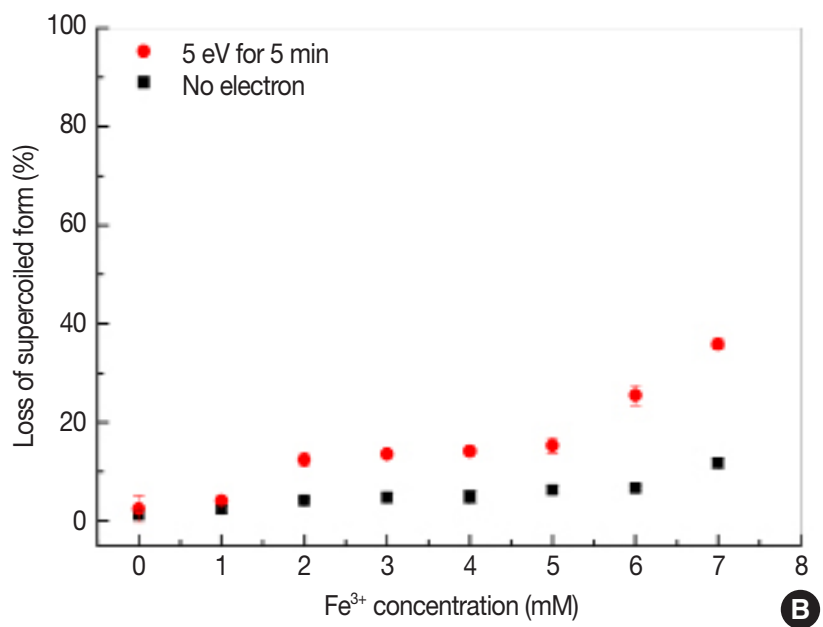

Fig. 1. (A) Loss of supercoiled DNA by the combined effect of LEE-irradiation and $\mathrm{Cu}^{2+}$ ion. The solid circles indicate the results for 5 eV electron irradiations on DNA-Cu${ }^{2+}$ complex and the solid squares indicate the result without electron irradiation, respectively. Error bars at $0 \mathrm{mM}$ are unseen because they are smaller than the data points. (B) Loss of supercoiled DNA by the combined effect of LEE-irradiation and $\mathrm{Fe}^{3+}$ ion. The solid circles indicate the results for $5 \mathrm{eV}$ electron irradiations on DNA-Fe ${ }^{3+}$ complex and the solid squares indicate the result without electron irradiation, respectively [16].

Table 1. Yields of Total Damage for Non-irradiated and $5 \mathrm{eV}$ Electron-irradiated DNA-Cu+ ${ }^{2+}$ Comlexes

\begin{tabular}{|c|c|c|c|}
\hline $\begin{array}{l}\mathrm{Cu}^{2+} \text { concentration } \\
(\mathrm{mM})\end{array}$ & $\begin{array}{l}\mathrm{SC} \text { loss due to } \mathrm{Cu}^{2+} \text { only } \\
\text { [No e-irradiation] }\end{array}$ & $\begin{array}{c}\mathrm{SC} \text { loss due to } \mathrm{Cu}^{2+} \text { and } \\
5 \mathrm{eV} \text { electron }\end{array}$ & $\begin{array}{l}\text { Enhancement due to combined effect of } \\
\mathrm{Cu}^{2+} \text { and } 5 \mathrm{eV} \text { electron }\end{array}$ \\
\hline $0\left[\mathrm{No} \mathrm{Cu}^{2+}\right]$ & $5.61 \pm 0.59$ & $12.16 \pm 0.90$ & $6.55[a]$ \\
\hline 1 & $4.88 \pm 1.29$ & $12.18 \pm 6.33$ & 0.75 \\
\hline 3 & $6.25 \pm 0.65$ & $21.73 \pm 5.92$ & 8.93 \\
\hline 5 & $10.20 \pm 1.78$ & $27.45 \pm 9.28$ & 10.70 \\
\hline 7 & $9.02 \pm 4.07$ & $25.88 \pm 12.14$ & 10.31 \\
\hline 9 & $7.77 \pm 3.54$ & $15.31 \pm 4.18$ & 0.98 \\
\hline 11 & $11.24 \pm 4.32$ & $29.32 \pm 16.89$ & 11.53 \\
\hline 13 & $13.35 \pm 1.93$ & $53.89 \pm 15.89$ & 33.99 \\
\hline 15 & $24.34 \pm 3.82$ & $73.74 \pm 17.89$ & 42.85 \\
\hline
\end{tabular}

All values in the last column, except value [a] =(Loss of SC DNA with LEE and $\left.\mathrm{Cu}^{2+}\right)-($ Loss of SC DNA with LEE only) $-($ LosS of SC DNA with Cu+ only). Value $[\mathrm{a}]=$ (Loss of SC DNA with $5 \mathrm{eV}$ irradiation)-(LOSS of SC DNA with no LEE irradiation). 

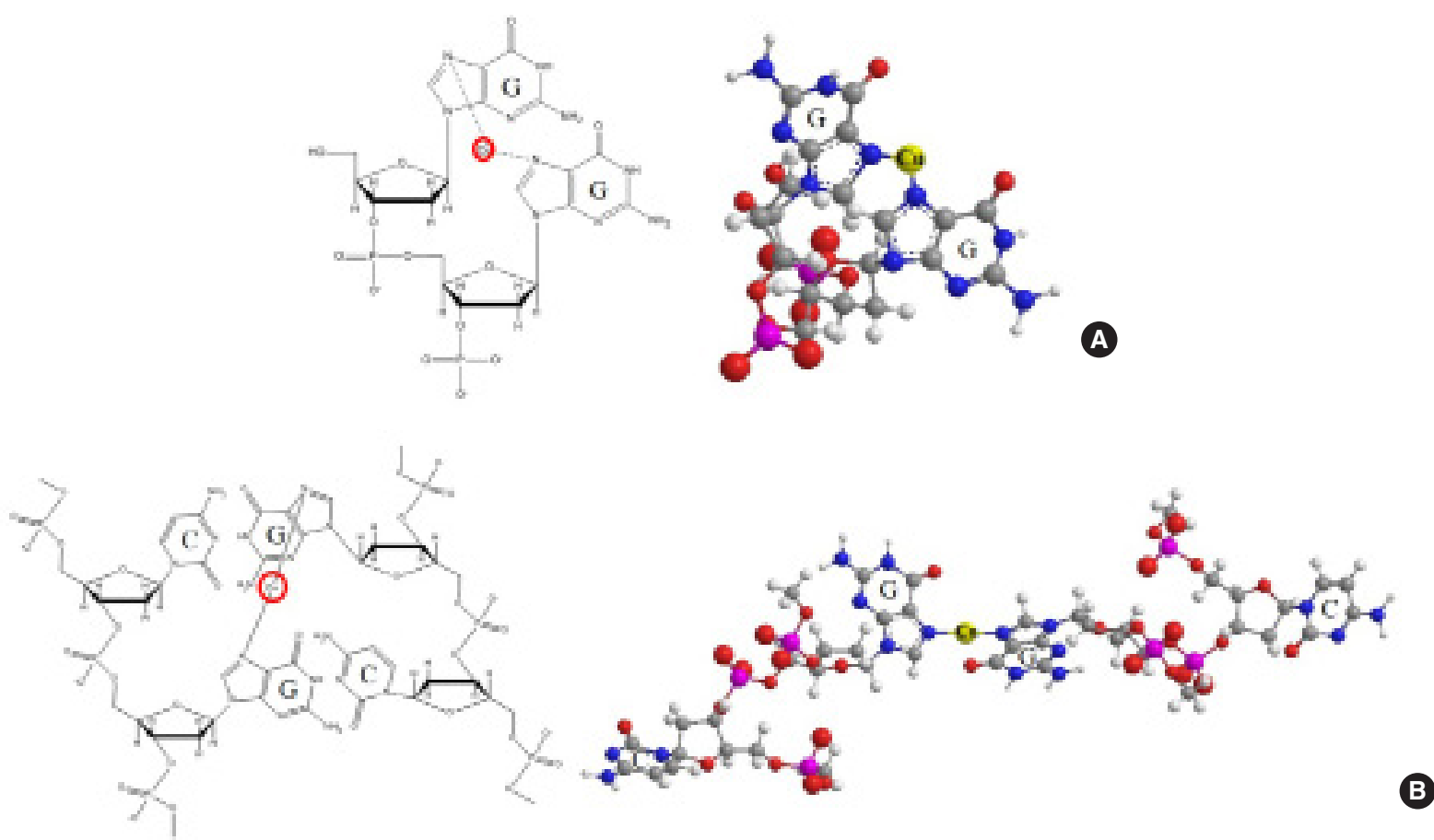

Fig. 2. The schematic drawings of intra- and inter-crosslinks between $\mathrm{Cu}$ ion and guanine bases. G-Cu-G intra-crosslink (A) and CG-CuGC inter-crosslink (B) show 2-D and 3-D images of G-G intra- and inter-crosslinks mediated by Cu ion, respectively.

eV electron irradiation and $\mathrm{Cu}^{2+}$ ion concentrations, respectively. Again, each point is an average of four to eight independent measurements with an error bar indicating the corresponding one standard deviation. In Table 1, the same results are tabulated for damage yields due to $\mathrm{Cu}^{2+}$ concentrations only and the combined effect of LEEs and $\mathrm{Cu}^{2+}$ ion. Each yield value is, as in the figure, expressed as an average percentage loss of supercoiled DNA, given with a corresponding standard deviation.

For the convenience of the comparison, the result for $\mathrm{Fe}^{3+}$ ion is reproduced in Figure 1B. In our original work on Fe ion, there are results for the electron energies of $3 \mathrm{eV}$ and 5 $\mathrm{eV}$ [16]. However, in Figure 1B, only the result for $5 \mathrm{eV}$ is given to compare with the $\mathrm{Cu}$ ion data. The general trend observed in $\mathrm{Cu}$ ion data looks similar to that of Fe ion, except in $\mathrm{Cu}$ ion case there is a prominent dip at $9 \mathrm{mM}$ concentration for the irradiated data. As can be seen in Figure 1A and Table 1, when only $\mathrm{Cu}^{2+}$ ion was added to supercoiled DNA (i.e., without LEE-irradiation), there was only a slight damage for the $\mathrm{Cu}^{2+}$ concentration range of 0 to $9 \mathrm{mM}$ and slowly started to increase from $11 \mathrm{mM}$ (see the solid square in Figure 1A). This damage might be generated by Fenton reaction of $\mathrm{Cu}^{2+}$ ion and $\mathrm{H}_{2} \mathrm{O}_{2}$ during the film preparation as previous $\mathrm{Fe}^{3+}$ case $[20,21]$. In the case when there was only LEE-irradiation on DNA with no $\mathrm{Cu}^{2+}$ ion, a little DNA damage of about $6.6 \%$ has occurred. In other words, a single effect of either $\mathrm{Cu}^{2+}$ ion or LEE-irradiation did not cause a significant damage. However, when these two components were combined, the DNA damage was increased quite significantly with increasing $\mathrm{Cu}^{2+}$ ion concentration except around $9 \mathrm{mM}$, compared to the sum of DNA damages caused by $\mathrm{Cu}^{2+}$ ion and by LEE-irradiation independently. At $5 \mathrm{eV}$ electron energy, most of DNA damage has been identified as SSB in the spectra of gel electrophoresis. In the previous experiment with Fe ion, we have done the experiments for the $\mathrm{Fe}^{3+}$ concentration from 0 to $7 \mathrm{mM}$, and above $7 \mathrm{mM}$ there was a sharp increase of damage which might be due to an extra mechanism other than Fenton reaction [16]. But in copper case, the beginning of damage decrease for the electron-irradiated samples was noticed, and therefore the measurements with $\mathrm{Cu}^{2+}$ ion concentration up to $15 \mathrm{mM}$ were made to observe and locate the dip around $9 \mathrm{mM}$.

As mentioned before, the overall trend of DNA damage by the combined effect of LEEs and $\mathrm{Cu}$ ion is similar to that of Fe ion. However, an interesting new observation in this study is a decreased DNA damage by $5 \mathrm{eV}$ electron irradiation at around $9 \mathrm{mM} \mathrm{Cu}^{2+}$ ion. It is believed that, at the $\mathrm{Cu}^{2+}$ ion concentration near $9 \mathrm{mM}$, the chemical structure of DNA-Cu${ }^{2+}$ 


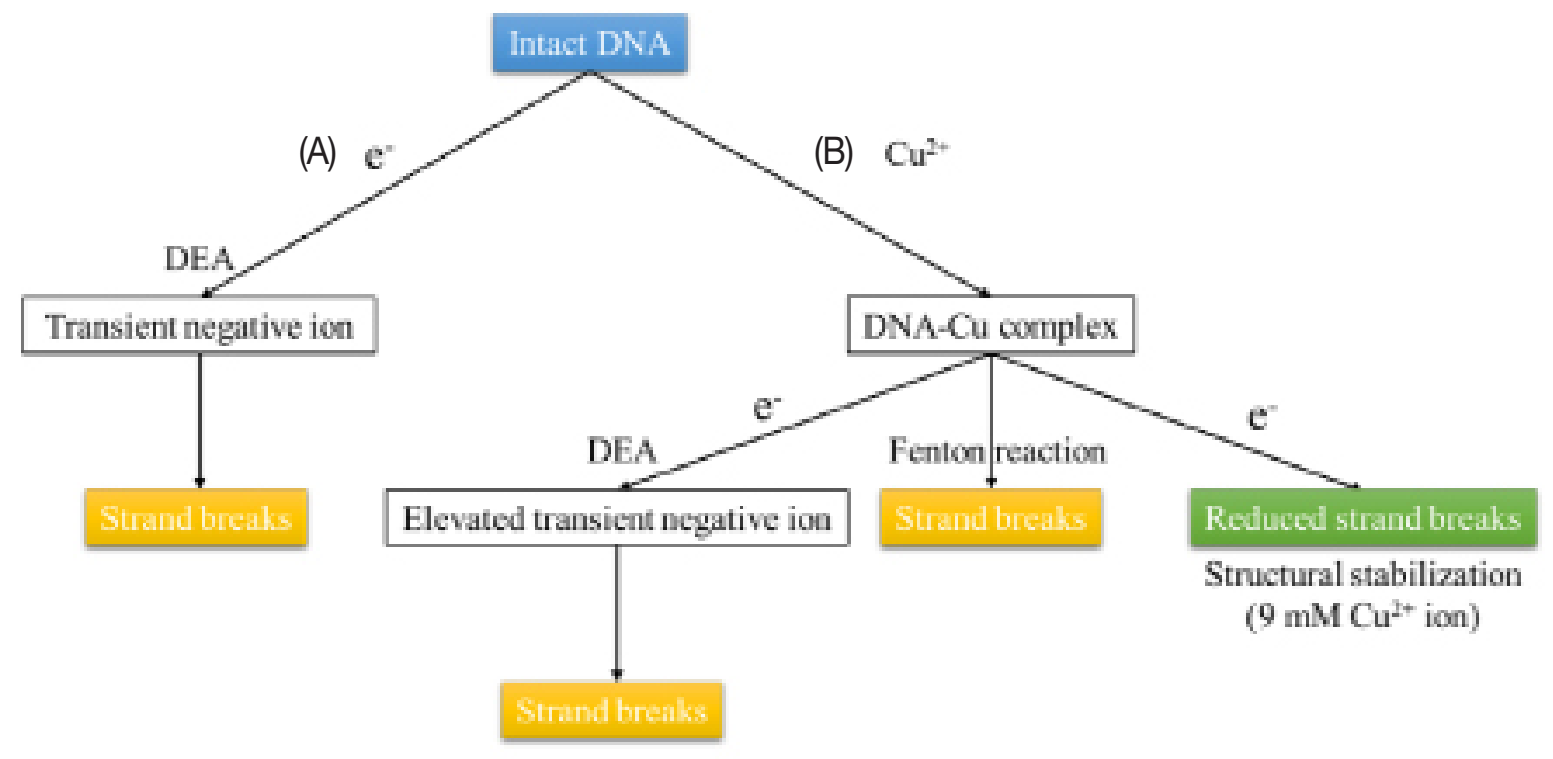

Fig. 3. The reaction pathways of DNA damage generated by single and combined effects of LEE-irradiation and $\mathrm{Cu}^{2+}$ ion. Path (A) and (B) show the fundamental DEA process, the combined effect of DEA and Fenton reaction and structural stabilization, respectively.

ion complex become stable to protect DNA from the damage by LEEs. Copper was found to bind DNA with high affinity and a crystal structure was formed between $\mathrm{CuCl}_{2}$ and DNA giving a copper-binding to $\mathrm{N} 7$ of guanine residue and forming a pseudo-octahedral geometry [22, 23]. It is pointed by Gao et al. [17] that $\mathrm{Cu}$ (II) ion can bind exclusively to N7 of guanines and is capable of pulling two guanines (G10 and \#G12 of CGCGTG) closer by about 1.5 Å to form a bis-coordination linkage. This suggests that $\mathrm{Cu}(\mathrm{II})$ ion may be very effective in causing inter- or intra-crosslinks between two different DNA duplexes, at least in the case of Z-DNA. Hay and Morris [24] proposed that copper may stabilize the helix via a charge transfer complex formed when copper, acting as an electron acceptor, intercalates between two adjacent G-C pairs which act as electron donors. Indeed, copper has been shown to bind preferentially to G-C pairs. This kind of stabilization may occur at a certain $\mathrm{Cu}^{2+}$ concentration and protect DNA from being damaged by LEEs. From the basis of these points, we suggest the possible chemical binding structures of guanines and $\mathrm{Cu}^{2+}$ ion. In Figure 2A, the neighboring guanines in a single strand can be crosslinked via making bonding with $\mathrm{Cu}$ ion. This intra-crosslink leads to a bending structure between guanine bases. In Figure 2B, the close opposite guanines in a double strand can also be crosslinked via making bonding with $\mathrm{Cu}$ ion. This inter-crosslink leads to a pulling structure between the guanine bases on the complementary DNA strands. In other words, the chemical structure of DNA duplex becomes stable via bending and pulling effects of intra- and inter-crosslinks on the single and double strands, respectively. This structural change might be capable of reducing the DEA processes due to the change of resonance energy level for capturing LEEs. Consequently, this leads to the decrease of DNA damage near $9 \mathrm{mMCu}$ ion.

The reaction pathways of DNA damage generated by single and combined effects of LEEs and $\mathrm{Cu}^{2+}$ ion are proposed in Figure 3. The fundamental damage process is DEA via LEE-irradiation as seen path (A) in Figure 3. This process has been well known and generally been accepted to explain DNA damage by collisions of LEEs (below $10 \mathrm{eV}$ ) [1, 16]. In the presence of $\mathrm{Cu}^{2+}$ ion, guanine base in DNA strand can preferentially interact with $\mathrm{Cu}^{2+}$ ion to form $\mathrm{DNA}-\mathrm{Cu}^{2+} \mathrm{com}$ plex. Fenton reaction is main cause of DNA damage without LEE-irradiation, and this damage is generally less than that induced by LEEs. LEE-irradiation on DNA-Cu ${ }^{2+}$ complex is capable of increasing DNA damage through the elevated DEA process. However, in a certain concentration of $\mathrm{Cu}^{2+}$ ion (9 $\mathrm{mM}$ in this experiment), DNA damage by LEE-irradiation is conversely decreased due to structural stabilization. These processes are summarized in Figure 3 path (B). To fully understand DNA damage or protection mediated by LEEs and transition metal ions, it requires more experimental and theoretical evidences. 


\section{Conclusion}

The low energy electron-induced DNA damage in the presence of $\mathrm{Cu}^{2+}$ ion was investigated. The single effect of LEE collision or $\mathrm{Cu}^{2+}$ ion on the yield of DNA damage does not exceed $20 \%$, while the combined effect of two causes was significantly increased up to $43 \%$ as a function of $\mathrm{Cu}^{2+}$ ion concentration. Interestingly, a protection-like effect at around $9 \mathrm{mM} \mathrm{Cu}^{2+}$ ion on LEE-induced DNA damage was observed. The possible DNA damage pathways for the mechanism involved was suggested. For fully understanding whole mechanisms, it needs further studies.

\section{Acknowledgments}

This work was supported by research fund of Chungnam National University in 2015.

\section{References}

1. Boudaiffa B, Cloutier P, Hunting D, Huels MA, Sanche L. Resonant formation of DNA strand breaks by low-energy (3 to $20 \mathrm{eV}$ ) electrons. Science. 2000;287:1658-1660.

2. Lu QB, Sanche L. Condensed-phase effects of absolute cross sections for dissociative electron attachment to CFCs and FCFCs adsorbed on Kr. J. Chem. Phys. 2003;119:2658-2662.

3. Lu QB, Sanche L. Enhancement in dissociative electron attachment to CF4, chlorofluorocarbons and hydrofluorocarbons adsorbed on $\mathrm{H}_{2} \mathrm{O}$ ice. J. Chem. Phys. 2004;120:2434-2438.

4. Christophorou LG, McCorkle DL, Christodoulides AA. ElectronMolecule Interactions and Their Applications. 1st Ed. New York, NY. Academic Press.1984;478-558.

5. Chutjian A, Garscadden A, Wadehra JM. Electron attachment to molecules at low electron energies. Phys Rep. 1996;264:393-470.

6. Ying ZC, Ho WJ. Photodissociation of adsorbed MO(CO)6 induced by direct photoexcitation and hot-electro attachment. 2 . Physical mechanisms. J. Chem. Phys. 1991;94:5701-5714.

7. Sanche L. Nanoscopic aspects of electronic aging in dielectrics. IEEE Trans. Dielectr. Electr. Insul. 1997;4:507-543.

8. Lu QB, Sanche L. Effects of cosmic rays on atmospheric chlorofluorocarbon dissociation and ozone depletion. Phys. Rev. Lett. 2001;87:078501.
9. Aruoma OI, Halliwell B, Gajewski E, Dizdaroglu M. Copper-iondependent damage to the bases in DNA in the presence of hydrogen-peroxide. Biochem J. 1991;273:601-604.

10. Keyer K, Imlay JA. Superoxide accelerates DNA damage by elevating free-iron levels. Proc. Natl. Acad. Sci. USA. 1996;93:1363513640 .

11. Kasprzak KS. Oxidative DNA and protein damage in metal-induced toxicity and carcinogenesis. Free Radic. Biol. Med. 2002; 32:958-967.

12. Gao YG, Sriram M, Wang AH. Crystallographic studies of metalion DNA interactions-different binding modes of cobalt(III), copper(II) and barium(II) to N-7 of guanines in Z-DNA and a drug-DNA complex. Nucleic. Acid Res. 1993;21:4093-4101.

13. Lloyd DR, Phillips DH. Oxidative DNA damage mediated by copper(III), iron(II) and nickel(II) Fenton reactions. Mutation Res. 1999;424:23-36.

14. Walling C. Fenton's reagent revisited. Acc. Chem. Res. 1975;8: 125-131.

15. Walling C, Goosen A. Mechanism of the ferric ion catalyzed decomposition of hydrogen peroxide. Effect of organic substrates. J. Am. Chem. Soc. 1973;95:2987-2991.

16. Park Y, Noh HA, Cho H. Effect of low-energy electron irradiation on DNA damage by $\mathrm{Fe}^{3+}$ ion. Radiation Res. 2012;177:775-780.

17. Gao YG, Sriram M, Wang AHJ. Crystallographic studies of metal ion - DNA interactions: Different binding modes of cobalt(II), copper(II) and barium(II) to N7 of guanines in Z-DNA and a drug- DNA complex. Nucleic. Acid. Res. 1993;21:4093-4102.

18. Borkow G, Gabby J. Copper as a biocidal tool. Current Medicinal. Chem. 2005;12:2163-2175.

19. Theophanides T, Anastassopoulou J. Copper and carcinogenesis. Critical Reviews in Oncology / Hematology. 2002;42:57-64.

20. Tushar KD, Mas RW, Kaneez FS. Oxidative stress gated by Fenton and Haber Weiss reactions and its association with Alzheimer's disease. Arch. Neurosci. 2015;2:e20078.

21. Wojciech B, Dazimierz SK. Induction of oxidative DNA damage by carcinogenic metals. Toxicol. Lett. 2002;127:55-62.

22. Kagawa TF, Geierstanger BH, Wang AHJ, Shing Ho P. Covalent modification of guanine bases in double-stranded DNA. J. Biol. Chem. 1991;266:20175-20184.

23. Geierstanger GH, Kagawa TF, Chen SL, Guigley GJ, Shing Ho P., Base-specific binding of coffer(II) to Z-DNA. J. Biol. Chem. 1991; 266:20185-20191.

24. Morris P, Hay RW. In Metal ions in biological sciences Vol.5; Sigel, H. Ed. New York, NY. Marcel Dekker. 2001;173-243. 